\title{
POTRET PERIKANAN TANGKAP TUNA, CAKALANG DAN LAYANG DI KOTA BITUNG
}

\author{
Cornelia Mirwantini Witomo dan Budi Wardono
}

Balai Besar Penelitian Sosial Ekonomi Kelautan dan Perikanan

JI. KS. Tubun Petamburan VI Jakarta 10260

Telp. (021) 53650162, Fax. (021)53650159

Diterima 23 Feb 2012- Disetujui 24 Mei 2012

\begin{abstract}
ABSTRAK
Tujuan penulisan ini adalah memberikan gambaran keragaan perikanan tangkap di Kota Bitung, Sulawesi Utara. Komoditas utama perikanan tangkap Kota Bitung adalah tuna, cakalang dan layang. Kota Bitung memiliki satu Pelabuhan Perikanan Samudera (PPS) yang keberadaannya sangat strategis. Pendaratan ikan di PPS Bitung berasal dari tangkapan kapal-kapal nelayan sekitar dan nelayan jaring pukat cincin (purse seine), pancing (hand line), rawai (long line) serta kapal pengumpul dan pengangkut. Armada penangkapan di Kota Bitung sebagian besar adalah alat tangkap menggunakan mata pancing seperti pancing tuna, rawai tuna, pancing ulur karena ini berpengaruh dengan nilai jual ikan yang tertangkap khusus ikan tuna dan ikan cakalang. Jumlah perusahaan/ UPI yang bergerak dalam bidang perikanan tangkap dan eksportir di Kota Bitung sebanyak 35 perusahaan. Pada umumnya jenis ikan yang di ekspor adalah tuna. Jalur ekspor ikan tuna dari Kota Bitung yaitu melalui laut dan udara.
\end{abstract}

Kata Kunci: nilai ekonomi, perikanan tangkap, Bitung, keragaan, komoditas ekspor

\section{Abstract : Capture Fisheries Economic Value of Tuna, Skipjack and Flying Fish in Bitung. By : Cornelia Mirwantini Witomo and Budi Wardono..}

The purpose of this paper is to provide general overview of capture fisheries in Bitung City, North Sulawesi. Main commodities of capture fisheries from Bitung City are tunas, skipjack and scad. Bitung City has Ocean Fishing Port (PPS) that has very strategic role. This fishing port serves fish landing derived from fishing vessel that using purse seine, hand line, long line and from collecting fishing vessel. The numbers of fish processing unit whose engaged in capture fisheries and exporters in Bitung are 35 companies. Tuna is a main export commodity from fisheries in Bitung. The exploitation of tuna is shipped by air and sea.

Keywords: economic value, capture fisheries, Bitung, performance, export commodity

\section{PENDAHULUAN}

Perairan Indonesia meliputi perairan laut dalam dan ZEE (Zona Ekonomi Eksklusif) memiliki sumberdaya ikan sebesar 6,4 juta ton per tahun. Selama 5 dasawarsa, pemanfaatan sumberdaya ikan tersebut terus meningkat rata-rata sebesar $5,45 \%$ setiap tahunnya. $\mathrm{Hal}$ ini terkait dengan kemajuan teknologi alat tangkap yang semakin maju dan meningkatnya kemampuan dan jumlah perusahaan dan RTP (Rumah Tangga Perikanan) nelayan (Moeslim et al., 2006).

Indonesia sebagai negara eksportir perikanan urutan ke-11 didunia dengan nilai ekspor US\$ 2,7 milyar (P2HP, 2008). Komoditas produk perikanan yang diekspor adalah tuna segar dan beku, udang beku, tilapia segar/beku dalam bentuk utuh dan fillet, rumput laut, ikan hias, Tujuan negara-negara eksportir dari hasil produk perikanan Indonesia adalah Jepang, Amerika Serikat serta negara-negara Uni Eropa.

Kota Bitung merupakan salah satu sentra produksi perikanan di Indonesia. Lokasi Kota Bitung sangat strategis terletak di antara dua wilayah pengelolaan perikanan yaitu perairan Laut Maluku (WPP-715) dan perairan Laut Sulawesi (WPP-716). Kota Bitung memiliki Pelabuhan Perikanan Samudera (PPS) yang ditetapkan oleh Peraturan Menteri KP No. PER.19/ MEN/2008 pada tanggal 6 Oktober 2008 tentang Perubahan atas Peraturan Menteri Kelautan dan Perikanan No Per 06/MEN/2007 tentang Organisasi dan Tata Kerja Pelabuhan Perikanan. Fungsi dari PPS Bitung sebagai penyedia sarana dan prasarana pelabuhan seperti dermaga, kolam pelabuhan, tempat perlengkapan ikan, kantor administratif adalah (1) meningkatkan kualitas pelayanan; (2) mengimplementasikan unit bisnis perikanan terpadu; (3) mengoptimalisasikan pusat informasi pelabuhan perikanan; (4) mengimplementasikan outer ring fishing port development; (5) pengembangan PPS yang memiliki wilayah potensial dan wilayah perbatasan; (6) perluasan dukungan lintas sektor dan subsektor; (7) menunjang pelaksanaan tugas pokok dan fungsi PPS (Sitanggang etal., dalam BBPSEKP, 2011). Tujuan penulisan ini adalah untuk memberikan gambaran keragaan perikanan tangkap di Kota Bitung. 


\section{PERIKANAN TANGKAP TUNA, CAKALANG DAN LAYANG}

\section{A. Produksi Hasil Tangkapan}

Komoditas utama perikanan tangkap Kota Bitung adalah tuna (Thunnus spp), cakalang (Katsuwonus pelamis) dan layang (Decapterus spp). Komoditas yang menjadi andalan ekspor adalah tuna sedangkan untuk cakalang dan layang menjadi pasokan untuk pasar lokal. Kota Bitung sebagai salah satu lokasi keluar masuknya komoditas perikanan di wilayah timur Indonesia. Kota Bitung memiliki satu Pelabuhan Perikanan Samudera (PPS) yang keberadaannya sangat strategis. Pendaratan ikan di PPS Bitung berasal dari tangkapan kapal-kapal nelayan sekitar dan nelayan purse seine, hand line, long line serta kapal pengumpul dan pengangkut. Pada Tabel 1 dapat terlihat produksi hasil tangkapan perikanan di Kota Bitung yang secara umum mengalami peningkatan.

Kegiatan operasional PPS Bitung sebagai pelabuhan mencakup pelaksanakan tugas produksi dan pemasaran hasil perikanan di Kota Bitung, pengawasan pemanfaatan sumberdaya dan pelestarian dan kelancaran kegiatan kapal perikanan serta pelayanan kesyahbandaran di pelabuhan perikanan (Anwar, 2011). Kegiatan operasional PPS Bitung tahun 2009 - 2010 terlihat dari Tabel 2. Apabila dilihat dari volume ikan yang didaratkan, terjadi peningkatan hasil tangkapan. $\mathrm{Hal}$ ini disebabkan oleh pertambahan jumlah dan jenis ikan yang tertangkap bertambah dan peningkatan frekuensi bongkar muat jenis kapal motor di atas 30 GT meningkat.

Peningkatan produksi perikanan di Kota Bitung ternyata belum dapat memberikan kontribusi penerimaan negara secara signifikan. Lebih lanjut ternyata banyak tangkapan yang berasal dari Indonesia didaratkan di Pelabuhan General Santos yang berada di Filipina. Akibat yang terjadi adalah turunan bahan baku untuk industri pengolahan nasional tidak dapat dipenuhi. Kondisi saat ini, aktivitas bongkar muat di Pelabuhan Kota Bitung baru sekitar 50 ton per hari, jauh dibawah kapasitas Pelabuhan General Santos yaitu 700 ton per hari (Satyono et.al., 2006).

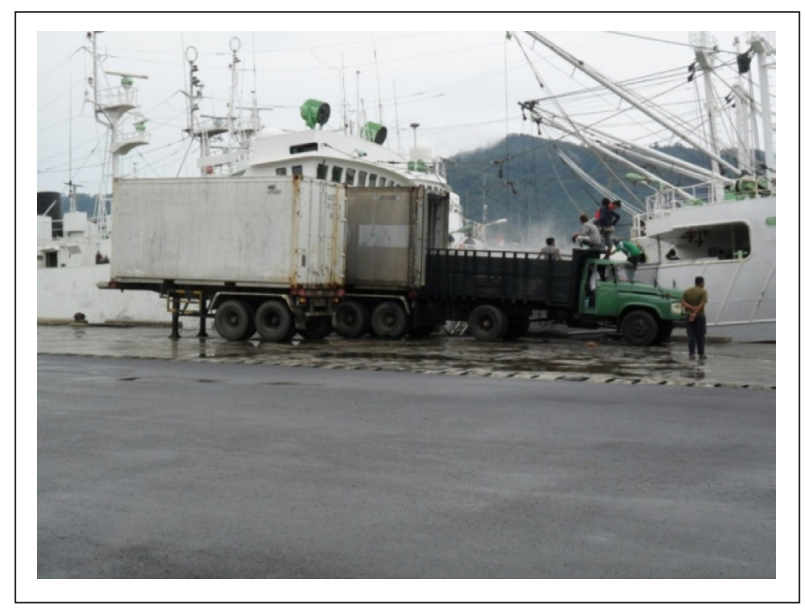

Gambar 1. Salah Satu Kegiatan di Pelabuhan Perikanan Samudra Bitung Berupa Bongkat Muat Tuna.

Armada penangkapan di Kota Bitung sebagian besar adalah alat tangkap menggunakan mata pancing seperti pancing tuna, rawai tuna dan pancing ulur (Tabel 3). Jenis alat tangkap tersebut berpengaruh terhadap nilai jual ikan yang tertangkap khususnya ikan tuna dan ikan cakalang.

Tabel 1. Volume Produksi Hasil Tangkapan di Kota Bitung Tahun 2004 - 2009.

\begin{tabular}{|c|c|c|c|c|c|c|c|c|}
\hline \multirow{2}{*}{ No } & \multirow{2}{*}{ Jenis Ikan } & \multicolumn{6}{|c|}{ Volume (ton) Per Tahun } & \multirow{2}{*}{$\begin{array}{c}\text { Persentase } \\
\text { Kenaikan/ } \\
\text { Penurunan } \\
\text { Produksi } \\
\text { 2004-2009 } \\
\end{array}$} \\
\hline & & 2004 & 2005 & 2006 & 2007 & 2008 & 2009 & \\
\hline 1. & Cakalang & $52.802,4$ & $54.910,2$ & $55.394,4$ & $57.360,1$ & $59.475,1$ & $61.364,8$ & 13,95 \\
\hline 2. & Albakora & $14.196,1$ & $13.450,0$ & $12.794,6$ & $12.926,9$ & $15.178,7$ & $15.313,5$ & 7,30 \\
\hline 3. & $\begin{array}{l}\text { Tuna } \\
\text { Madidihangfggg }\end{array}$ & $14.363,2$ & $14.967,4$ & $14.680,8$ & $13.277,7$ & $13.701,0$ & $14.419,3$ & 0,39 \\
\hline 4. & Tuna Mata Besar & $13.429,7$ & $13.041,6$ & $13.177,0$ & $12.216,5$ & $12.513,8$ & $12.611,7$ & $-6,49$ \\
\hline 5. & Layang & $22.113,4$ & $22.195,5$ & $21.036,4$ & $22.794,0$ & $23.610,8$ & $22.452,1$ & 1,51 \\
\hline 6. & Tongkol Abu-abu & $14.161,7$ & $13.263,8$ & $13.362,4$ & $14.268,6$ & $14.864,2$ & $16.555,4$ & 14,46 \\
\hline
\end{tabular}


Tabel 2. Kegiatan Operasional PPS Bitung Tahun 2009 - 2010.

\begin{tabular}{|c|c|c|c|c|c|}
\hline \multirow[b]{2}{*}{ No } & \multirow[b]{2}{*}{ Kegiatan } & \multirow[b]{2}{*}{ Satuan } & \multicolumn{2}{|c|}{ Tahun } & \multirow{2}{*}{$\begin{array}{l}\text { Presentase } \\
\text { (\%) Kenaikan/ } \\
\text { Penurunan }\end{array}$} \\
\hline & & & 2009 & 2010 & \\
\hline 1 & Produksi Ikan & Ton & 15.599 & 17.704 & 13,5 \\
\hline 2 & Nilai Produksi & $\mathrm{Rp}$ & 185.372 .734 .669 & 200.913.170.538 & 8,38 \\
\hline 3 & Frekuensi Kunjungan Kapal & Kali & 21.432 & 18.262 & $-14,79$ \\
\hline 4 & Penerimaan Bukan Pajak & $\mathrm{Rp}$ & 221.945 .970 & 279.005.389 & 25,709 \\
\hline \multirow[t]{8}{*}{5} & Penyaluran Perbekalan & & & & \\
\hline & - Es & Balok & 110.374 & 400.000 & 362,304 \\
\hline & - Air & Liter & 3.452 .000 & 6.850 .000 & 76,27 \\
\hline & - Garam & $\mathrm{Kg}$ & 7.655 & 98.250 & 1,183 \\
\hline & - Solar & Liter & 10.312 .655 & 15.309 .178 & 48,45 \\
\hline & - Minyak Tanah & Liter & 198.652 & 987.000 & 391,8 \\
\hline & - Oli & Liter & 23.150 & 117.550 & 407,78 \\
\hline & - Bensin & Liter & 58.000 & 44.150 & $-23,88$ \\
\hline
\end{tabular}

Sumber : Direktorat Jenderal Perikanan Tangkap (2011)

Kualitas ikan yang akan diolah sangat ditentukan proses penangkapannya. Berdasarkan hasil wawancara ikan-ikan yang tertangkap dengan menggunakan jaring pukat cincin (purse seine) digunakan sebagai bahan baku kaleng. Sedangkan ikan yang tertangkap dengan menggunakan pancing (pole and line) digunakan sebagai ikan gelondongan, bahan baku untuk ikan beku (frozen), loin, dan saku.
Berdasarkan alat tangkap yang digunakan, jenisjenis ikan yang tertangkap di sekitar perairan Bitung adalah ikan pelagis kecil dan besar serta demersal (Tabel 4). Dari segi volume total ikan yang tertangkap mengalami peningkatan. Walaupun tuna mengalami peningkatan, namun berdasarkan hasil wawancara, pasokan tuna untuk unit pengolah ikan Kota Bitung masih kurang.

Tabel 3. Armada Penangkapan Berdasarkan Alat Tangkap di Kota Bitung Tahun 2010.

\begin{tabular}{|c|c|c|c|c|c|}
\hline \multirow{2}{*}{ No } & \multirow{2}{*}{ Alat Tangkap } & \multicolumn{4}{|c|}{ Kapal Penangkap dan Pengangkut } \\
\hline & & $<5$ GT & $5-10 \mathrm{GT}$ & $10-30 \mathrm{GT}$ & $>30 \mathrm{GT}$ \\
\hline 1 & Pancing Tuna & 114 & 48 & & \\
\hline 2 & Soma Pajeko & 1 & 114 & 54 & \\
\hline 3 & Bagan Apung & 1 & & & \\
\hline 4 & Sero & 1 & & & \\
\hline 5 & Kapal Pengangkut & 1 & & 40 & 237 \\
\hline 6 & Kapal Lampu & & 35 & 37 & 103 \\
\hline 7 & Rawai Tuna & & & 10 & 83 \\
\hline 8 & Pancing Ulur & & & 85 & 5 \\
\hline 9 & Huhate & & & 10 & 40 \\
\hline 10 & Jaring Insang Hanyut Oceanik & & & & 35 \\
\hline 11 & Pukat Cincin Pelagis Kecil (PK) & & & & 45 \\
\hline 12 & Pukat Cincin Pelagis Besar (PB) & & & & 65 \\
\hline 13 & Pancing Rawai Dasar & & & & 9 \\
\hline 14 & Pancing Cumi & & & & 6 \\
\hline 15 & Pukat Ikan & & & & 4 \\
\hline \multirow[t]{2}{*}{16} & Payang & & & & 5 \\
\hline & Jumlah & 118 & 197 & 236 & 637 \\
\hline
\end{tabular}

Sumber : Dinas Kelautan Perikanan Kota Bitung (2011) 
Tabel 4. Jenis Ikan yang Tertangkap di Perairan Kota Bitung Berdasarkan Alat Tangkap Pukat Pancing (Purse Seine) dan Pancing (Pole and Line) yang didaratkan di PPS Bitung Tahun 2009 dan 2010.

\begin{tabular}{|c|c|c|c|}
\hline \multirow{2}{*}{ NO } & \multirow{2}{*}{ JENIS IKAN } & \multicolumn{2}{|c|}{ TAHUN } \\
\hline & & 2009 & 2010 \\
\hline 1 & Layang (Decapterus spp) & 3.442 .984 & 3.401 .735 \\
\hline 2 & Tongkol (Thunnus maccoyii) & 760.003 & 616.778 \\
\hline 3 & Sardin (Sardinella spp) & 23.113 & 182.641 \\
\hline 4 & Cakalang (Katsuwonus pelamis) & 9.211 .776 & 9.660 .527 \\
\hline 5 & Tuna (Thunnus spp) & 1.101 .677 & 2.830 .945 \\
\hline 6 & Selar (Selaroides spp) & 415.446 & 246.405 \\
\hline 7 & Kembung (Rastellinger spp) & 115.055 & 11.312 \\
\hline 8 & Teri (Stolephorus spp) & 127.999 & 82.846 \\
\hline 9 & Lamadang (Coryphaena spp) & 74.111 & 3.723 \\
\hline 10 & Gurita (Octopus spp) & 3.841 & - \\
\hline 11 & Sunglir (Elagastis bipinnulatus) & 17 & 2.501 \\
\hline 12 & Cumi (Mastigoteuthis flammea) & 9.779 & 5.000 \\
\hline 13 & Kakap (Lutjanus spp) & 38.723 & 50.912 \\
\hline 14 & Tengiri (Scomberomorus spp) & 33.889 & 200.840 \\
\hline 15 & Bawal (Pampus spp) & 16.796 & 64.168 \\
\hline 16 & Marlin (Makaira spp) & 25.051 & 51.067 \\
\hline 17 & Kwee (Caranx Sexfasciatus) & 111 & 51.444 \\
\hline 18 & Kerapu (Ephinepelus spp) & 222 & 22.278 \\
\hline 19 & Hiu (Carcharinus leucas) & 175.833 & 95.556 \\
\hline 20 & Lolosi (Caesio caerulaurea) & 167 & - \\
\hline 21 & Meka (Xiphias gladius) & - & 3.878 \\
\hline 22 & Sako (Tylosurus crocodiles) & - & 278 \\
\hline 23 & Kababida & - & 29.000 \\
\hline 24 & Layang anggur (Decapterus kurroides) & - & 51.389 \\
\hline 25 & Kakap Putih (Lates calcarifer) & - & 7.223 \\
\hline 26 & Kurisi (Nemipterus nematuphurus) & - & 32.445 \\
\hline 27 & Campuran & 5.222 & - \\
\hline & TOTAL VOLUME & 15.581 .815 & 17.704.891 \\
\hline
\end{tabular}

Sumber : Direktorat Jenderal Perikanan Tangkap (2011)

\section{B. Perkembangan Ekspor Perikanan}

Realisasi ekspor perikanan di Kota Bitung dari tahun 2004 hingga tahun 2009 menunjukan adanya fluktuasi volume dan nilai (Tabel 5). Jenis ikan yang umumnya diekspor dari PPS Kota Bitung adalah tuna. Jalur ekspor ikan tuna dari Kota Bitung yaitu melalui laut dan udara. Jika melalui laut, jalur ekspor menggunakan kapal ekspedisi langsung menuju negara tujuan ekspor, sedangkan melalui udara, menggunakan maskapai komersil dengan jalur : Bitung - Manado - Jakarta atau Bali - negara tujuan ekspor. Ada tiga jenis harga beli ikan tuna berdasarkan grade, namun harga tersebut bisa berubah-ubah tergantung kondisi pasar luar negeri selain tergantung musim, juga dipengaruhi oleh mutu tuna dari negara eksportir lain (Kementerian UMKM, 2009). Penentuan grade berdasarkan penilaian keadaan fisik daging yang terdapat pada dekat sírip dorsal atau sírip ekor ikan. Tingkatan A díberikan pada daging yang berwarna merah terang dan tidak terdapat atau terdapat sedikit pelangi pada sayatan daging serta rasa daging masih manis. Tingkatan B díberikan pada daging yang berwarna merah agak gelap, terdapat pelangí típis dan rasa dagíng terasa sedíkít asam (Widiastuty, 2009). Tabel 6 menyajikan varian harga beli ikan tuna berdasarkan tingkatannya.

Berdasarkan hasil wawancara, kapasitas produksi Unit Pengolahan Ikan (UPI) di Kota Bitung saat ini mencapai 900 ton/hari dengan pasokan bahan mentah dari Kota Bitung sebesar $40 \%$ dan $60 \%$ dari luar Kota Bitung. Kurangnya pasokan bahan baku menjadi kendala bagi UPI di Kota Bitung dalam rangka memenuhi target ekspor masing-masing UPI tersebut. Nelayan yang menjadi pemasok bahan baku mentah untuk UPI adalah nelayan pamboat. 
Tabel 5. Nilai Ekspor Perikanan Kota Bitung Tahun 2004 - 2009.

\begin{tabular}{ccccc}
\hline No & Tahun & Volume (ton) & Nilai (US \$) & $\begin{array}{c}\text { Persentase (\%) Kenaikan/ Penurunan } \\
\text { Nilai Ekspor }\end{array}$ \\
\hline 1. & 2004 & $49.748,73$ & $91.462 .338,14$ & \\
2. & 2005 & $29.554,30$ & $63.196 .912,58$ & $-44,73$ \\
3. & 2006 & $43.431,97$ & $46.183 .510,35$ & $-36,84$ \\
4. & 2007 & $31.556,84$ & $62.860 .722,08$ & 26,53 \\
5. & 2008 & $37.633,86$ & $88.526 .407,47$ & 28,99 \\
6. & 2009 & $26.634,23$ & $82.140 .283,40$ & $-7,77$ \\
\hline
\end{tabular}

Sumber: Dinas Kelautan dan Perikanan Kota Bitung (2010)

Tabel 6. Harga Beli Ikan Tuna Berdasarkan Tingkatan di Kota Bitung Tahun 2010.

\begin{tabular}{ccc} 
No & Tingkatan & Harga Perkilogram (Rp) \\
\hline 1. & A & $30.000-40.000$ \\
2. & B & $25.000-30.000$ \\
3. & C & $<25.000$ \\
\hline
\end{tabular}

Sumber: Data Primer (2011)

Nelayan pamboat adalah nelayan tradisional. Setiap satu unit penangkapan pamboat terdiri dari empat orang yaitu nahkoda dan anak buah kapal. Setiap kapal dilengkapi dengan sekoci kecil yang berfungsi untuk menangkap ikan tuna sampai ke rumpon dengan menggunakan alat tangkap pancing/ hand line. Jumlah tangkapan ikan tuna rata-rata delapan sampai sepuluh ekor dengan berat rata-rata bisa mencapai $30 \mathrm{~kg}$ per/ekor. Hasil tangkapan nelayan pamboat lainnya yaitu ikan layang dan cakalang. Biaya yang dikeluarkan untuk satu trip melaut rata-rata Rp 2.000.000,-
Belakangan ini telah terjadi perubahan alat tangkap di nelayan pamboat dari jaring pukat cincin mini/mini purseseine menjadi alat tangkap pancing (hand line). Berdasarkan hasil wawancara, dasar pemilihan alat tangkap pancing karena alat tangkap ini lebih selektif, lebih ekonomis dan ramah lingkungan serta harga jual tangkapan relatif lebih tinggi karena kualitasnya lebih bagus dan dapat dijadikan bahan baku ekspor. Jalur distribusi ikan tuna sebelum diekspor di Kota Bitung adalah melalui rantai dari jaringan pengumpul kecil ke pengumpul besar dan ke UPI untuk selanjutnya diekspor (Gambar 2).

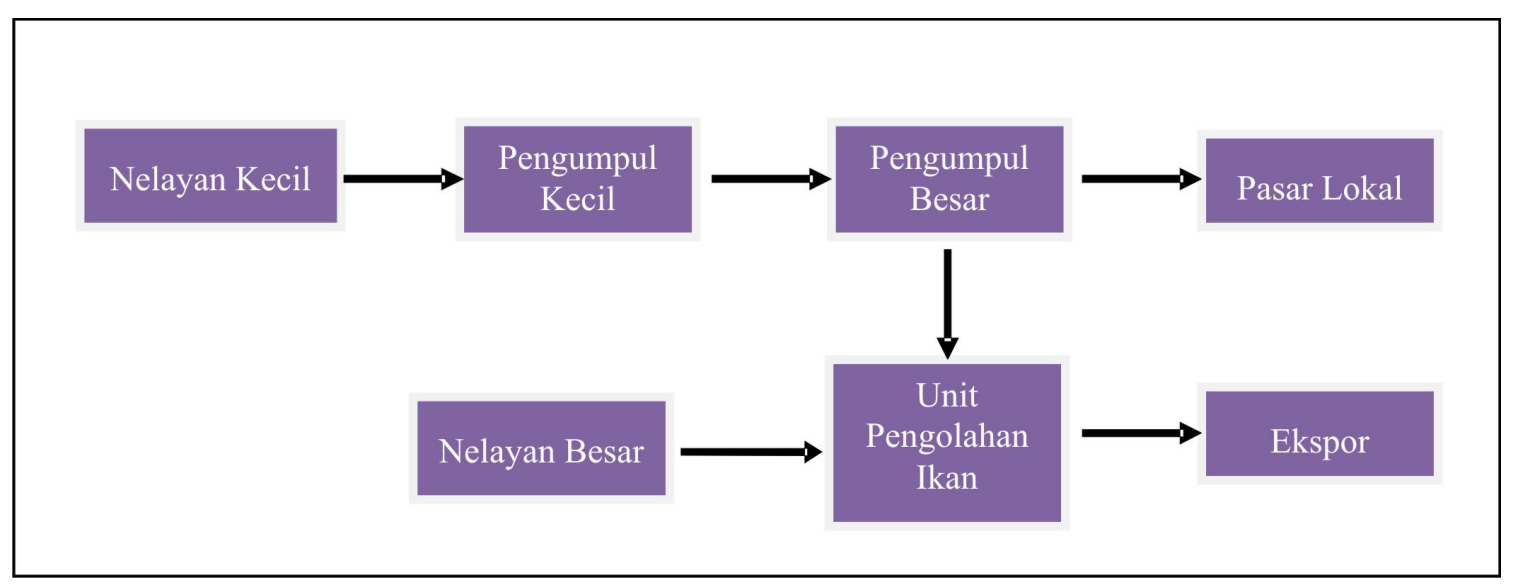

Gambar 2. Jalur Distribusi Ikan Tuna sebelum di Ekspor di Kota Bitung 


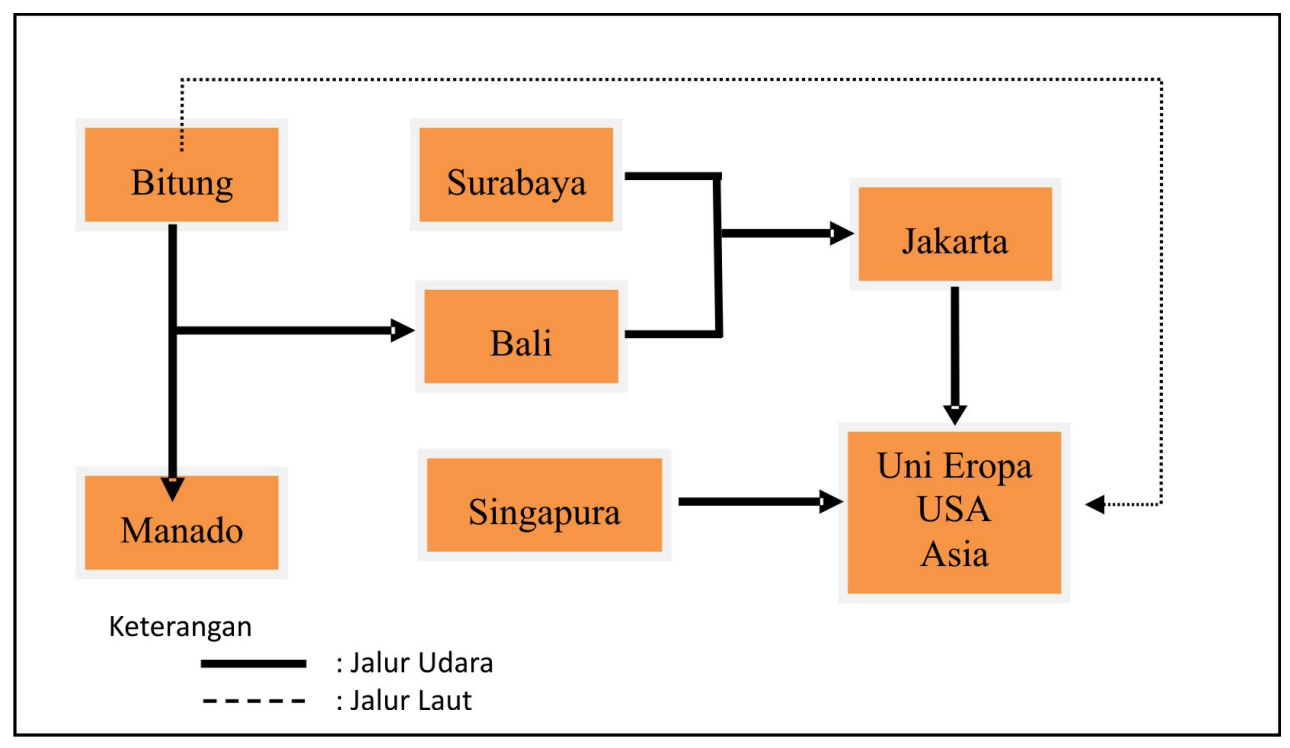

Gambar 3. Jalur Ekspor Ikan Tuna Dari Kota Bitung ke Negara Tujuan

Berdasarkan hasil wawancara kendala yang dihadapi eksportir adalah jalur ekspor yang terlalu panjang khususnya jika melalui jalur udara dan kuota pengiriman yang terbatas. Selain itu adanya aturan penggunaan sterofoam khusus oleh maskapai penerbangan komersil yang tidak bisa dipindahkan atau ditransitkan. Eksportir tidak boleh mengirim barang ekspor dengan pindah maskapai apabila maskapai sebelumnya mengalami keterlambatan. Sebagai contoh apabila dari Bitung/Manado menggunakan maskapai A menuju Bali, namun ketika di Bali maskapai A mengalami keterlambatan menuju Jakarta, eksportir tidak dapat mengirim barang tepat waktu karena aturan sterofoam melarang barang tersebut dikirim menggunakan maskapai lainnya yang menuju Jakarta. Apabila barang tidak dikirim segera maka akan merusak kualitas barang tersebut dan membuat rugi para eksportir. Biaya yang dikeluarkan untuk pengiriman melalui udara berkisar US\$ $3-4$ per/kilogram. Jalur ekspor yang terlalu panjang menjadi kendala para eksportir (Gambar 3) karena memakan waktu dan biaya pengiriman. Berdasarkan hasil wawancara eksportir memilih jalur keluar ekspor melalui Bali saja tidak perlu ke Jakarta lagi.

\section{Investasi dan Pengembangan Industri Pengolah Ikan}

Perusahaan Unit Pengolahan Ikan (UPI) yang bergerak dalam bidang perikanan tangkap di Kota Bitung terdata sebanyak 35 perusahaan UPI yang hampir seluruhnya adalah eksportir. Berdasarkan hasil wawancara, kendala untuk mengembangkan usaha pengolahan ikan terkait dengan perikanan tangkap khususnya di dalam kawasan PPS Bitung adalah masalah pembebasan lahan. Berdasarkan Keputusan Menteri Kelautan Perikanan No. 62/MEN/2011 tentang Wilayah
Kerja dan Wilayah Pengoperasian PPS Bitung, luas total wilayah kerja daratan dan perairan 19,6 ha dan luas total wilayah pengoperasian mencapai 103 ha. Hal ini menunjukkan dari segi ketersediaan lahan ada prospek pengembangan usaha pengolahan ikan terkait dengan perikanan tangkap.

\section{KESIMPULAN}

Dengan dukungan berupa sarana dan prasarana pelabuhan dan perusahaan pengolah, maka sektor perikanan Kota Bitung memiliki potensi yang cukup besar untuk menjadi salah satu sentra perikanan tangkap di Indonesia, khususnya Indonesia bagian timur. Dalam memanfaatkan potensi tersebut terdapat kendala dan hambatan yang tidak mudah mulai dari sisi penangkapan, pengolahan hingga sisi distribusi produk yang dihasilkan dapat mengakibatkan kurang optimalnya pemanfaatan potensi tersebut. Oleh karena itu, diperlukan revitalisasi PPS Bitung sebagai upaya optimalisasi pemanfaatan potensi berupa peningkatan fasilitas bongkar muat serta pelayanan penyediaan fasilitas suplai kebutuhan operasional armada penangkapan dan pelayanan perbaikan alat tangkap.

\section{DAFTAR PUSTAKA}

Anwar, A.K. 2011. Penyuluh Perikanan Tenaga Kontrak (PPTK) IV . (Online). Available at : http:// poetragor.blogspot.com/2011/03/penyuluhperikanan-tenaga-kontrak-pptk_1685.html. Verified on : 18 Desember 2011

Balai Besar Penelitian Sosial Ekonomi Kelautan Perikanan. 2011. Laporan Teknis Minapolitan Tangkap Laut. BBPSEKP Balitbang KP KKP. Jakarta. 
Dinas Kelautan Perikanan Kota Bitung. 2010. Statistik Perikanan Kota Bitung Tahun 2009. Dinas Kelautan Perikanan Kota Bitung. Bitung.

2011. Statistik Perikanan Kota Bitung Tahun 2010. Dinas Kelautan Perikanan Kota Bitung. Bitung.

Direktorat Jenderal Perikanan Tangkap. 2011. Laporan Tahunan Pelabuhan Perikanan Samudera Tahun 2010. Bitung.

Kementerian UMKM. 2009. Pola Pembiayaan Usaha Kecil Usaha Pengolahan Tuna Loin. Jakarta.

Moeslim, S dan F. Cholik. 2006. Usaha Perikanan di Indonesia. 60 Tahun Perikanan Indonesia. Masyarakat Perikanan Nusantara. Jakarta.
Satyono, E dan A. Jauzi.2006. Konsepsi Optimalisasi Pemanfaatan Potensi Sumberdaya dan Investasi Perikanan yang Tersedia dalam Rangka Meningkatkan Produksi Perikanan Indonesia. 60 Tahun Perikanan Indonesia. Masyarakat Perikanan Indonesia. Jakarta.

Widiastuty, I. 2009. Analisis Mutu Ikan Tuna Selama Lepas Tangkap Pada Perbedaan Preparasi dan Waktu Penyimpanan. (Online). Available at : https:// docs.google.com/viewer?a=v\&q=cache: 75 KtyJhJwsJ:www.damandiri.or.id/file/indahwid iastutyipbbab4df+aspenentuan+grade+tuna\& $\underline{\mathrm{hl}=i d \& g|=i d \& p i d=b| \& \text { srcid=ADGEESiaugU9Twc }}$ IMxv j6jiviUV uoTs33f-QDUQTziqg8zF1ymZoV WODrmqa2uYNviRtGhTwWEeHtCYv-aCock6e2N7gahjdV7ODWaXYolcQCal-IUqAJXbHsb5UJ1g N4ksCzBMQh\&sig=AHIEtbRHDHnsLWsBOU4Af6 XAJ5-QMLjFVw. Verified on : 18 Desember 2011. 